\title{
Evaluation of the Role of Political and Communication Skills in Social Responsibility of Managers by the Mediating Role of Strategic Thinking
}

\author{
Hamid Taboli \\ Associate Professor of Payame Noor University, Tehran, Iran \\ Ghazanfar Baghadam \\ Phd Student of Public Administration - Human Resource Management, Islamic Azad University, Kerman, Iran

\begin{abstract}
The research has been conducted to evaluate the role of political and communication skills in social responsibility of managers by the mediating role of strategic thinking. This research was done by descriptive - analytic method and it is from the type of applied researchs. The statistical population of the study includes all managers of the company of Arjan, Pegah. The sample size was calculated by Cochran formula with the result of 32 people. Data collection tools in this study are: Corporate Social Responsibility of employees (CSR) based on the model of Carroll, Barton's communication skills questionnaire, political skill questionnaire of individual in organization and strategic thinking questionnaire (model Lydka). The validity of the questionnaire was face and content, and its reliability was assessed by Cronbach's alpha coefficient. The results showed that, in general, political skill, communication skill and strategic thinking had a direct and significant relationship with responsibility of managers. Path analysis also showed that among the different aspects of research variables, feedback skill, network skill, social intelligence, strategic determination, opportunism and thinking at the time had direct impact and listening skill, network skill and social intelligence had indirect effect on social responsibility as well.
\end{abstract}

Doi:10.5901/mjss.2016.v7n4s1p323

Keywords: social responsibility, communication skill, political skill, strategic thinking, managers.

\section{Introduction}

Social responsibility is a sense of obligation to make a personal reaction in various situations because of commitment to others. A sense of commitment to others, adherence to rules and social norms and understanding the rules of group, which has formed in the mind of person and affect his behaviors (Sobhaninejad, 2000). According to Conrad and Hayden, social responsibility of a person have a responsive tendency, feels competency in order to operate responsibly, finds himself effective in relation to responding activities, and acts responsibly (Singapagdy, 1996). The purpose of social responsibility is that organizations have huge impact on the social system; therefore, the way of their activities should be in such a way whereby no harm comes about, and in the case of any harm, the related organization to be required to compensate it (Werner, 2009). Wang Yong (2009) believes that the organizations involved in social responsibility can attract customers' positive perspective toward evaluating the commercial brand, selecting and recommending it to others and have good attitude and image toward the organization and even satisfaction of additional payments (Ibid). Skill consists of the ability of converting knowledge into action, so that leads to the optimal performance. The management skills are the skills, by which one sees the possibility to mobilize the components of a system in himself in order to move all the components properly toward the goal (Alaghe band, 2007). Management is among those jobs that the dominance in communication skills is the infrastructure of efficiency and success in it. The tasks that can be performed within manager's practice domain include planning, organizing, controlling and supervision, leadership and motivation, communication, and decision-making. Among the above-mentioned responsibilities, the role of communication skills is obvious and direct in communication dimension and hidden, but still positive, lies in other tasks. Because each one is realized within the framework of a process of communication and interaction (Ghorbani, 1999). Managers of different levels are responsible for providing proper communication in an organization; therefore, they must be aware of the quality and quantity of communication process and know how to communicate effectively. One of the skills of managers is the technique of behavior with employees or in other words, communication skills (Mirkamali, 1999). The communication skill is one of the most important skills and it is also as a working tool of educational leaders, which has significant impact on their success and effectiveness (Helriger, 1996). Abraham considers strategic thinking as identifying trusted strategies or 
business models that bring a value for the customer. He believes that the search for an appropriate strategic alternative, which is usually done as a part of the process of strategic management, actually, is the practical result of strategic thinking (Rezaeian, 2005). Gerets considers the role of strategic thinking as an effort for innovation and the embodiment of a new future and very different for organization, which may lead to redefinition of the principal strategies or even industrial in which the company operates (Mehrban, 2009). Political skills are a set of actions that managers employ to develop usefulness and avoid any losses in the organization, they (Duaei, 2005). Political skills are unique manner of social skill, which is changeable over the time through education, experience and supervision (Vandermat, 2008). Political skill is beyond the ease and convenience of communication and focuses on the management of interaction with others effectively so that it leads to achieve individual and organizational objectives (Frazer et al., 2005; Hoquater et al., 2007; Brewer et al., 2006). The instrumental nature of the political skill is associated by achieving the target. Therefore, political skill is a distinct form of social skill, which its aim is to achieve success and realize the goals in the individual and organizational levels. This skill can take place out of the organizational realm, but the goal is penetration and organizational success (Frazer et al., 2007). According the results mentioned in this research, it has tried to examine the relationship between communication and political skills with social responsibility by the mediating role of strategic thinking among managers in accordance with the following pattern.

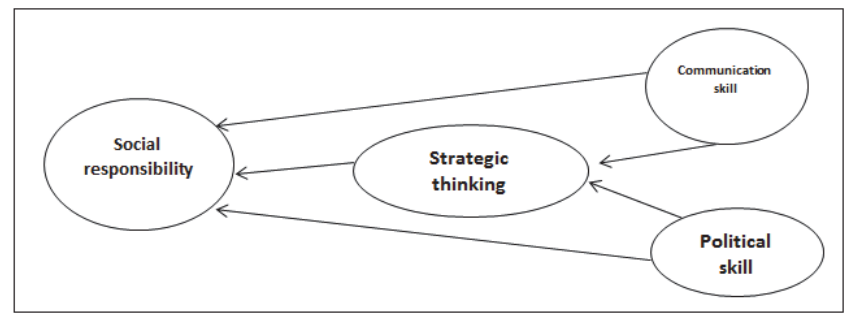

Figure 1: Research Model

\section{Theoretical Fundamentals}

Carol (1979) presented three-dimensional model of corporate social responsibility for social issues of organization in which the first dimension is social reporting, the second dimension is to identify social problems related to social reporting of organization and the third dimension is the philosophy of accountability and motivation of organization to respond to the relevant social challenges, which implies humanitarian attitude. In 1986, Vartik and Cochran extended social model and considered the social performance of the organization as social responsibility, social accountability and management of public issues that their dimensions are shown in Table 1.

Table 1: Extension of corporate social performance model. Sources: Shafei and Aziz (2013)

\begin{tabular}{|l|l|l|}
\hline (A) social responsibility & (B) Corporate social accountability & (C) Management of public issues \\
\hline 1) Economic perspective & 1) Passive Strategy & 1) Identifying the issues \\
2) Legal perspective & 2) Defensive strategy & 2) Analyzing the issues \\
3) Moral perspective & 3) Adaptation strategy & Which leads to organizational tendencies: \\
4) Discretion perspective & 4) Preventive strategy & \\
\hline $\begin{array}{l}\text { Which leads to a philosophical tendencies: } \\
\text { * The codification of organization's social contract }\end{array}$ & $\begin{array}{l}\text { Leading to institutional tendencies: } \\
\text { * Capacity building to respond to social changing conditions }\end{array}$ & *Determining corporate social policies \\
& * The development of responsiveness & \\
\hline
\end{tabular}

Swanson (1995) in his studies introduced corporate social performance model in three processes, A) Economy, which represents the ability of organization (CSP) for efficient conversion of input to output, B) Environmental, which represents an integrated and consistent relationships between the organization and the environment; and C) Deliberation of power, which represents behaviors based on strengthening the issue and self-focused situation (Mark, 2000). On the other hand, in the framework provided by Suarez and Carroll (2003), four dimensions are intended for corporate social responsibility that include:

Economic dimension: Since the primary responsibility of any business is, make a profit, in the economic dimension, which is the most important aspect of social responsibility, the primary objectives of organization, activities and economic 
measures are considered.

Legal dimension: By determining a set of rules and regulations by legal authorities and binding organizations and citizens to observe them and to move within the framework of the laws and regulations, the second dimension of social responsibility takes shape. This dimension is also known as social commitment.

Ethical dimension: Organizations are expected to consider values like other members of society, respect norms and beliefs of others, and take into account the ethical criteria in their activities. This dimension, also called as social accountability.

National and public dimension: the dimension includes expectations, demands and policies of top managers at the macro level, because it is expected that administrators and managers of organizations in addition to having a comprehensive attitude, consider general interest as main program of their decisions (Robbins, 1379).

In many other studies, which conducted for CSR, three areas have been introduced including: internal environment (including the physical environment of organization and working conditions), external environment (including communication with customers, suppliers of raw materials and the environment) and spirituality (including moral ads) (Sanaye, et al., 2009). Christopher (2004) in his classification of the concept of corporate social responsibility, refers to the internal-external dimensions of it, in which the inner dimensions contain healthiness and safety of staff and the accountability of managers in this regard, and it consists of a more limited range of stakeholders as well. If the outer dimensions included how to interact and comply with local and social environments, the greater range of stakeholders would involve. According to Ackerman (2005), the aim of accountability should be in the direction of corporate social objectives in three dimension of top management, expert staff and sectional managers. Porter and Kramer (2006) argue that the social responsibility rotates around the axes of compulsion to standardization, implementation instructions, continuity and stability. The purpose of the standard element is that, companies must be good citizens. The instruction implies that the companies should be accountable for the company's shareholders. The dimension of continuity emphasizes that the improvement of the company's image and the reinforcement of its brand are among the achievements of social responsibility and finally, the stability rotates around the concept of social and environmental monitoring of the activities of the company (Dahlsrud, 2008).

Table 2: Stages of maturity of social responsibility in organizations. Source: Aras et al. (2009)

\begin{tabular}{|l|l|l|l|}
\hline Step & Prominent feature & Related Activities & Example \\
\hline 1 & Exhibiting & $\begin{array}{l}\text { Redesigning reports related to social } \\
\text { responsibility }\end{array}$ & $\begin{array}{l}\text { Changing language and segmenting in order to } \\
\text { reflect the language of social responsibility }\end{array}$ \\
\hline 2 & Cost containment & Business Process Reengineering & Energy efficiency programs \\
\hline 3 & Covering stakeholders & Developing the balanced scorecard & Satisfaction survey \\
\hline 4 & Measurement and Reporting & Good progress of measures & Social responsibility reports \\
\hline 5 & Stability & $\begin{array}{l}\text { The definition of stability: Reengineering } \\
\text { Process }\end{array}$ & Sustainability report \\
\hline 6 & Transparency & Disclosure and concern about supply chain & Implementation of human rights \\
\hline 7 & Accountability & Reconfiguring the supply chain & Changing country's values \\
\hline
\end{tabular}

Table 3: Public perspectives of social responsibility in business

\begin{tabular}{|c|c|c|}
\hline Point of view & The role of business in society & Source \\
\hline $\begin{array}{l}\text { Net economic profitability } \\
\text { perspective }\end{array}$ & $\begin{array}{l}\text { Business has low moral standards as compared to society, and it has no social responsibility but } \\
\text { obeying the law. }\end{array}$ & \multirow{3}{*}{$\begin{array}{l}\text { Lima } \\
(2011)\end{array}$} \\
\hline $\begin{array}{l}\text { Fixed economic } \\
\text { profitability perspective }\end{array}$ & Business must maximize assets of shareholder, abides by the law, and become moral. & \\
\hline $\begin{array}{l}\text { Moral-social awareness } \\
\text { perspective }\end{array}$ & Business activity must be vigilant before potential losses on interest groups. & \\
\hline $\begin{array}{l}\text { Social services- } \\
\text { humanitarian perspective }\end{array}$ & Business must use its wide interest to service to the community. & \multirow{2}{*}{$\begin{array}{l}\text { Baron } \\
(2007)\end{array}$} \\
\hline Financial perspective & $\begin{array}{l}\text { Shareholders are the owners of the company and managers are the representatives and agents } \\
\text { who their duty is the more favorable realization of the wishes of the owners of shares. }\end{array}$ & \\
\hline
\end{tabular}

Existing theories concerning corporate social responsibility show that this concept has experienced optimal development in the last decades. In Table 3, we can see that the concept of social responsibility on what general aspects of the existing variables put emphasis on more. 


\section{Research Hypotheses}

1. There is a significant relationship between communication skill and its dimensions with social responsibility.

2. There is a significant relationship between political skill and its dimensions with social responsibility.

3. There is a significant relationship between strategic thinking and its dimensions with social responsibility.

4. Communication skill and political skill have an impact through strategic thinking on responsibility managers.

\section{Method}

This research was done by descriptive - analytic method and it is from the type of applied researches. The statistical population of the study includes all managers of the company of Arjan, Pegah. The sample size was calculated by Cochran formula with the result of 32 people.

\section{Research Tools}

Data collection tools in this study are:

Corporate social responsibility (CSR) questionnaire based on Carroll model: The questionnaire has 25 questions and 4 key dimensions: 1) Legal dimension 2) Ethical dimension 3) Humanitarian dimension 4) Economic dimension. The questions related to each of the dimensions of social responsibility can be seen in Table 4 . The questions related to the dimensions of social responsibility: Economic dimension: 1-6, Legal dimension: 7-13, Ethical dimension: 14-21, Humanitarian dimension: 22-25. Experts using the content validity confirmed the validity of this questionnaire in the research of Samadi (2013) and its reliability using Cronbach's alpha coefficient was calculated 0.92 and reported to be very favorable. In this study, Cronbach's alpha coefficient was obtained 0.94 for the whole questionnaire and $0.80,0.77$, 0.86 and 0.76 were obtained for economic, legal, ethical and humanitarian dimensions, respectively.

Barton's communication skills questionnaire: the questionnaire contains 18 questions and has three components: verbal, listening and feedback skills. In this questionnaire, feedback skills are measured by questions of 1-5-9-11-13-16, listening skills by questions of 2-6-8-10-14-18 and verbal skills by 3-4-7-12-15-17. This questionnaire has Likert scale, and it is scored by five choices of very disagree to very agree (1 to 5 ). Reliability and validity of communication skills of the manager has been confirmed in the research of Raiesi et al. Its reliability in the research of Alizadeh Same (2008) obtained 0.9 that indicates high reliability. In this study, Cronbach's alpha coefficient for the whole questionnaire of communication skill was 0.77 and for each of the dimensions of feedback, listening and verbal skills respectively 0.71 , 0.68 and 0.73 .

The questionnaire of political skill of person in the organization: This questionnaire contains 10 questions that measure the political skill of a person in the organization. The measuring dimensions by using the questionnaire are: Network skill: Questions from 1 to 5 and Social awareness: Question from 6 to 10. The using scale is a 5-point Likert scale. In this study, Cronbach's alpha coefficient for the whole questionnaire of political skill was 0.89 and for each of its dimensions, network and verbal skills 0.83 and 0.82 , respectively.

The questionnaire of strategic thinking assessment (Lydka model):

The questionnaire has 28 questions, which measures strategic thinking in 5 dimensions of 5-point Likert scale. Strategic thinking indicators and the questions related to each indicator are: systematic thinking: 1 to 6 , strategic determination: 7 to 14, progress on the basis of scientific approach: 15 to 17, intelligent opportunism: from 18 to 24 and thinking at the time: 25 to 28. In this research, Cronbach's alpha coefficient for the entire questionnaire of the strategic thinking is 0.78 , and for each of its components, systemic thinking $(0.74)$, strategic determination $(0.7)$, progress on the basis of scientific approach (0.67), intelligent opportunism (0.73) and thinking at the time (0.81).

\section{Findings}

Correlation and path analyses were used to test hypotheses and research model. 
Table 4: Correlation matrix of communication skill and social responsibility

\begin{tabular}{|c|c|c|c|c|c|c|c|c|c|c|}
\hline 9 & 8 & 7 & 6 & 5 & 4 & 3 & 2 & 1 & \multicolumn{2}{|l|}{ Variables } \\
\hline & & & & & & & & & Feedback & 1 \\
\hline & & & & & & & & $0 / 42^{*+*}$ & Listening & 2 \\
\hline & & & & & & & $0 / 57^{\text {t* }}$ & $0 / 32^{*}$ & Verbal & 3 \\
\hline & & & & & & $0 / 57^{\text {*t }}$ & $0 / 53^{\text {t* }}$ & $0 / 40^{*+1}$ & Communication skill (total) & 4 \\
\hline & & & & & $0 / 47^{\text {t* }}$ & $0 / 53^{\text {*t }}$ & $0 / 24$ & $0 / 21$ & Economic & 5 \\
\hline & & & & $0 / 523^{3 *}$ & $0 / 24$ & $0 / 24$ & $0 / 44^{\text {tit }}$ & $0 / 51^{\text {t* }}$ & Legal & 6 \\
\hline & & & $0 / 35^{*}$ & $0 / 474^{4+}$ & $0 / 30^{*}$ & $0 / 41^{*+}$ & $0 / 16$ & $0 / 18$ & Ethical & 7 \\
\hline & & $0 / 45^{\text {ti }}$ & $0 / 39^{\text {** }}$ & $0 / 25$ & $0 / 45^{\text {tit }}$ & $0 / 16$ & $0 / 20$ & $0 / 39^{\text {th }}$ & Humanitarian & 8 \\
\hline & $0 / 39^{*+*}$ & $0 / 52^{+*}$ & $0 / 61^{\text {t* }}$ & $0 / 523^{3 *}$ & $0 / 38^{*}$ & $0 / 33^{*}$ & $0 / 29$ & $0 / 35^{*}$ & Social responsibility (total) & 9 \\
\hline
\end{tabular}

Based on the results obtained from the correlation matrix (Table 4), there is a significant positive association between feedback skill and legal and humanitarian dimensions $(P<0 / 01)$. The relationship between feedback skill with an overall score of responsibility is significant $(P<0 / 05)$. There is not any significant relationship between feedback skill and other dimensions of responsibility $(\mathrm{P}>0 / 05)$. The relationship of listening skill with legal dimension in confidence level of 99 percent is positive and meaningful. However, listening skill had not any significant relationship with other dimensions and overall score of responsibility $(P>0 / 05)$. Between verbal skill and ethical and economic dimensions $(P<0 / 01)$ and responsibility (total) $(\mathrm{P}<0 / 05)$ significant direct relationship was observed. The relationship of verbal skill with legal and humanitarian dimensions in not significant $(P>0 / 05)$. In general, the relationship between communication skill and responsibility of managers is $0 / 38$.

Table 5: Correlation matrix of political skill and social responsibility

\begin{tabular}{|c|c|c|c|c|c|c|c|c|c|}
\hline 8 & 7 & 6 & 5 & 4 & 3 & 2 & 1 & \multicolumn{2}{|l|}{ Variables } \\
\hline & & & & & & & & Network skill & 1 \\
\hline & & & & & & & $0 / 56^{\text {** }}$ & Social awareness & 2 \\
\hline & & & & & & $0 / 55^{\text {** }}$ & $0 / 48^{\text {t* }}$ & Political skills (total) & 3 \\
\hline & & & & & $0 / 26$ & $0 / 37^{\star}$ & $0 / 18$ & Economic & 4 \\
\hline & & & & $0 / 47^{\text {t* }}$ & $0 / 48^{+*}$ & $0 / 40^{* *}$ & $0 / 58^{+*}$ & Legal & 5 \\
\hline & & & $0 / 523^{* *}$ & $0 / 24$ & $0 / 39^{+*}$ & $0 / 11$ & $0 / 66^{\text {t* }}$ & Ethical & 6 \\
\hline & & $0 / 35^{*}$ & $0 / 474^{* *}$ & $0 / 30^{*}$ & $0 / 28$ & $0 / 33^{*}$ & $0 / 22$ & Humanitarian & 7 \\
\hline & $0 / 45^{\text {th }}$ & $0 / 39^{+*}$ & $0 / 25$ & $0 / 45^{\text {th }}$ & $0 / 43^{\text {tit }}$ & $0 / 52^{\text {*t }}$ & $0 / 41^{\text {t* }}$ & Social responsibility (total) & 8 \\
\hline
\end{tabular}

The correlation matrix (Table 5) represents a relationship between political skill and dimensions of responsibility. According to the results, there is a significant positive correlation between network skill with legal and ethical dimensions $(\mathrm{P}<0 / 01)$. In addition, the relationship between network skill with overall score of responsibility is significant $(\mathrm{P}<0 / 01)$. There is no significant relationship between network skill and other dimensions of responsibility, $(P>0 / 05)$. The relationship of social intelligence with economic, legal and humanitarian dimensions and overall score of responsibility at least in confidence level is 95\% positive and meaningful. Social intelligence had no significant relationship with ethical dimension $(\mathrm{P}>0 / 05)$. In general, the relationship between political skill with responsibility of managers is $0 / 43$. 
Table 6: Correlation matrix of strategic thinking and social responsibility

\begin{tabular}{|c|c|c|c|c|c|c|c|c|c|c|c|c|}
\hline 11 & 10 & 9 & 8 & 7 & 6 & 5 & 4 & 3 & 2 & 1 & \multicolumn{2}{|l|}{ Variables } \\
\hline & & & & & & & & & & & Systematic thinking & 1 \\
\hline & & & & & & & & & & $0 / 61^{* *}$ & Strategic determination & 2 \\
\hline & & & & & & & & & $0 / 52^{* *}$ & $0 / 39^{* *}$ & Progress & 3 \\
\hline & & & & & & & & $0 / 39^{* *}$ & $0 / 44^{*+}$ & $0 / 35^{*}$ & Opportunism & 4 \\
\hline & & & & & & & $0 / 64^{*+}$ & $0 / 35^{*}$ & $0 / 36^{*}$ & $0 / 48^{*+}$ & Thinking at the Time & 5 \\
\hline & & & & & & $0 / 56^{*+}$ & $0 / 55^{\text {** }}$ & $0 / 37^{\star}$ & $0 / 41^{* t}$ & $0 / 44^{* *}$ & Strategic thinking (total) & 6 \\
\hline & & & & & $0 / 38^{\text {** }}$ & $0 / 48^{\text {** }}$ & $0 / 60^{* *}$ & $0 / 21$ & $0 / 53^{\text {t* }}$ & $0 / 33^{*}$ & Economic & 7 \\
\hline & & & & $0 / 45^{*+}$ & $0 / 41^{* *}$ & $0 / 52^{* *}$ & $0 / 46^{* *}$ & $0 / 19$ & $0 / 49^{* t}$ & $0 / 20$ & Legal & 8 \\
\hline & & & $0 / 20$ & $0 / 16$ & $0 / 33^{*}$ & $0 / 39^{* *}$ & $0 / 12$ & $0 / 26$ & $0 / 25$ & $0 / 32^{*}$ & Ethical & 9 \\
\hline & & $0 / 20$ & $0 / 20$ & $0 / 16$ & $0 / 30^{*}$ & $0 / 29^{*}$ & $0 / 24$ & $0 / 16$ & $0 / 35^{*}$ & $0 / 19$ & Humanitarian & 10 \\
\hline & $0 / 20$ & $0 / 20$ & $0 / 20$ & $0 / 16$ & $0 / 36^{* *}$ & $0 / 49^{* *}$ & $0 / 41^{*}$ & $0 / 22$ & $0 / 46^{* t}$ & $0 / 30^{*}$ & Social responsibility (total) & 11 \\
\hline
\end{tabular}

The correlation matrix of (Table 6) indicate the relationship between strategic thinking dimensions with responsibility dimensions. Based on the results, there is a direct and significant correlation between systematic thinking with economic, ethical and total responsibility. The relationship between strategic determination and the dimensions of economic, legal, humanitarian and total responsibility is positive and meaningful. There was no significant relationship between progress and responsibility dimensions. There is a direct and significant correlation between opportunism and the dimensions of economic, legal and total responsibility. The relationship between thinking at the time with all dimensions and total responsibility is positive and meaningful. In general, the relationship between strategic thinking with responsibility of managers is 0.36 .

\section{Path Analysis}

Path analysis is among multivariate techniques that in addition to examine direct effects of independent variables on the dependent variable, considers the indirect effects of these variables, and enters the relationships between variables in the analysis in accordance with the existing realities. In path analysis, the causal model obtained from the research is exhibited in path diagram. The path diagram is applied for visual expression of the relationships between the variables of interest in the analysis. Path diagram is a combination of whole paths that in the form of one-way arrows, connects the independent variables to the dependent variable. Each of these paths is specified with a path coefficient. Path coefficient is (Beta) in regression analysis that represents the contribution or weight of each independent variable in explaining the variance of the dependent variable. In performing path, the variables that have significant regression coefficient remain in the model, and the variables that their beta value in the error level of smaller than 0/05 are significant, the model will be deleted. According to the research model, the variables of communication and political skills are considered as endogenous variables, strategic thinking as dependent variables and responsibility, as the final dependent variable (exogenous). In order to do path analysis, multiple regression analysis was performed in two stages. In the first stage, the variable of social responsibility, as the dependent variable and the variables of communication and political skills and strategic thinking were considered as independent variables. In the second stage, the variable of strategic thinking as dependent variable and the variables of communication and political skills were entered as independent variables in multiple regression analysis. The results obtained from the path analysis test in the final research model can be seen in Figure 2. 


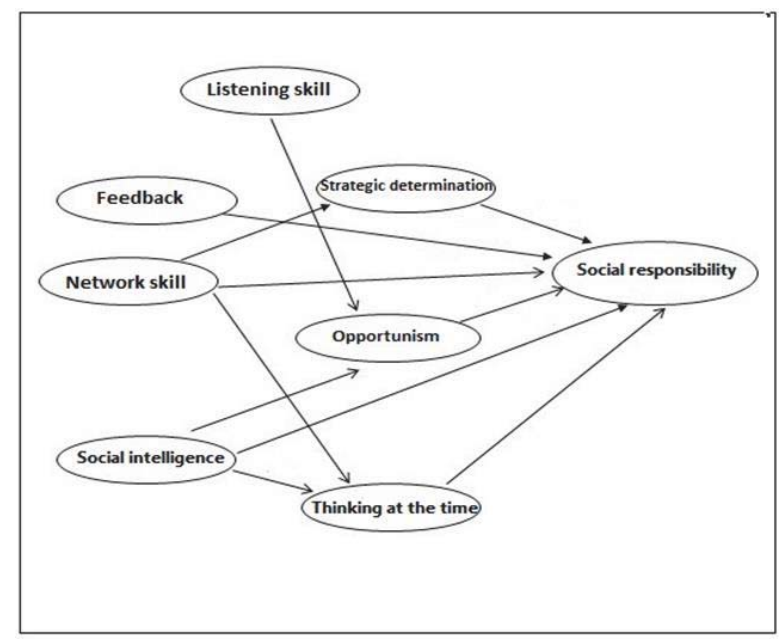

Figure 2: Path analysis and variables of path coefficients

According to path analysis, the path coefficient of direct (beta) for each of the variables affecting social responsibility are: Feedback skill (0.114), network skill (0.255), social intelligence (0.322), strategic determination (0.284), opportunism (0.221) and thinking at the time (0.314). The variables of listening skill, network skill and social intelligence also have an indirect effect on social responsibility. Table 7 shows the direct and indirect effects of each of the research variables based on path analysis.

Table 7: Direct and indirect effects of the research variables on social skills

\begin{tabular}{|c|c|c|c|c|}
\hline Total & Indirect effect & Direct effect & Predictor variables & Research variables \\
\hline 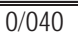 & $\overline{0 / 040}$ & $\overline{-1}$ & Listening skill & \multirow{3}{*}{ Communication skill } \\
\hline $0 / 114$ & - & $0 / 114$ & Feedback skill & \\
\hline- & - & - & Verbal skill & \\
\hline $0 / 4$ & $0 / 145$ & $0 / 255$ & Network skill & \multirow{2}{*}{ Political thinking } \\
\hline $0 / 42$ & $0 / 098$ & $0 / 322$ & Social intelligence & \\
\hline- & - & - & Systemic thinking & \multirow{5}{*}{ Strategic thinking } \\
\hline $0 / 284$ & - & $0 / 284$ & Strategic determination & \\
\hline- & - & - & Progress & \\
\hline $0 / 221$ & - & $0 / 221$ & Opportunism & \\
\hline $0 / 314$ & - & $0 / 314$ & Thinking at the time & \\
\hline
\end{tabular}

\section{Discussion and Conclusion}

In this research, it has tried to evaluate the role of political and communication skills in social responsibility of managers by the mediating role of strategic thinking. The results of the study showed that, overall, communication and political skills and strategic thinking have had a significant relationship with social responsibility of managers. The results of path analysis showed that the dimensions of political skill have had direct and indirect effects on social responsibility. Feedback skill had a direct impact on communication skill, while listening skill had an indirect impact on social responsibility. The components of strategic determination, opportunism and thinking at the time in the variable of strategic thinking have had a direct effect on the social responsibility of managers. Strategic thinking creates motivation and commitment to organization and its stakeholders. The motivation and commitment comes into being through the power that "in fact" is simple, and at the same time attractive. A big and integrated image (and also general and inaccurate) is taken shape in strategic thinking from the business environment. This approach is the required attitude to discover the effective rules and apply them in order to response to the customer. Analytical and rational dimensions of the strategy 
connect with its creative and artistic dimensions and as a result, a strong management approach can be achieved. All of the cases cause to increase in social responsibility toward the people and customers. On the other side, effective communications is one of the key elements of managers' success, because the information as an important data in the shadow of effective communications enters into organization, as soon as entering, it requires an efficient communication system to be processed and to be flowed like blood in vessels of organizations. Management is among the job categories, which dominance in the communication skills is the groundwork of success and efficiency in it. One of the factors that causes effective communication not to be established well is lack of knowledge of the source or sender of the exchanged consequences between itself and recipient in the process of communications. It gives the information feedback to the source in relation to the success in implementing the goals and as the matter of fact by doing so, it controls the future messages that the sender encode. Regarding the role of political skill, Bales and Frazer (2007) believe that people who have social perceptive are constantly looking out for others and social conditions and then modify their behavior accordingly and are able to identify social situations and personal interactions accurately that occur in these situations. They also have a great ability to persuade others and they apply the skill for different purposes (Frazer et al., 2008). People with social perceptive are able to interpret the behavior of others, understand social situations and are ingenious in relation to others. This form of political skill will affect the ability of employees to assess the best time and method to start the change (Kelly and Ford, 2011). These people are intelligent observers of their social environment, not only they understand the complexity of their surrounding but also their own motives and the motives of others (Frazen and Terdwei, 2012). Networking ability, as one of the dimensions of political skill implies that people are skilled in establishing connections, friendships and alliances. This capability creates a social capital, which equips people with more resources to fulfill the objectives and makes individual responsible (Peru et al., 2007). People, who have the ability to network properly, are able to establish useful and effective participation in the workplace with others successfully. Network ability is the strongest predictor of penetration tactics of upward request, alliances and determination (courage) (Frazer et al., 2008). People, who are high in political skill, identify those who have the beneficial resources or relationships and make social networks with them and gain social capital and social support in this way (Peru et al., 2007). In addition, the skilled politicians are able to manage conflicts and negotiations efficiently, which reinforces the possibility of establishing a stronger relationship with others (Frazenr and Terdwei, 2012).

\section{References}

Doai, H. (2005), "Providing appropriate organizational communications model in Iran National Steel Industrial Group", Management knowledge quarterly, No. 25. Publication of Faculty of Administrative Sciences and Business Management Tehran University.

Robbins, Stephen (2000), Organization theory, translated by Seyyed Mehdi Alwani and Hassan Danaei far. Tehran: Publication of Saffar.

Rezaeian, A. (2005), Organizational Behavior Management, Tehran: Publication of Semat.

Sobhaninejad, M. (2000), Social responsibility in today's elementary school curriculum in Iran and the design for the future, MSc thesis, Tarbiat Modarres University.

Shafi'i, R., Azizi, N. (2012), Study of corporate social responsibility at universities and higher education centers in the west of country (Designing a model assessment). Volume 1, Issue 2: 5-22.

Sanaei, Ali, Ali Safari and Samira Alizade (2008), Study of the effect of complying corporate social responsibility (CSR) in the protection of the environment, the first International Conference on Safety position, Health and Environment in organizations, Isfahan, Arvin Pishro trading company.

Alaghemand, A. (2007), Theoretical foundations and principles of educational management, Tehran, Ravan publication.

Ghorbani, N. (1999), Communication skills, infrastructure of efficient management, management development quarterly.

Mehrban, H. (2009). Relationship of managers' communication skills and organizational commitment of secondary school teachers, MSc Thesis, Ferdowsi University of Mashhad.

Mirkamali, M. (1999). Educational Leadership and Management, Fifth Edition, Tehran: Sitroun Publication.

Ackerman J. (2005). Social Accountability in the Public Sector, A Conceptual Discussion. Participation and Civic Engagement; (82): 352.

Aras G. Crowther D. (2009). Global Perspectives on Corporate Governance and CSR. Ashgate Publishing, Ltd. 2008.

Baron D. (2007). Corporate social responsibility and social entrepreneurship. Journal of Economics \& Management Strategy; 16(3): 683717.

Brouer, R. L., Ferris, G. R., Hochwarter, W. A., Laird, M. D., \& Gilmore, D. C. (2006). The strain-related reactions to perceptions of organizational politics as a workplace stressor: Political skill as a neutralizer. Handbook of organizational politics, 187, 206.

Carrol AB. (1991). The Pyramid of Corporate Social Responsibility: Toward the moral management of organizational Stakeholders. Business Horizon.

Christopher J, et al. (2004). Beyond The Quality Management paradigm, AUK Case study perspective on corporate social Responsibility. Cor. E. Research Group. 
Dahlsrud A. (2008). How corporate social responsibility is defined: An analysis of 37 definitions. Corporate Social Responsibility \& Environmental Management; 15(1): 1-13. doi:10.1002/csr.132.

Ferris, G. R., Treadway, D. C., Kolodinsky, R. W., Hochwarter, W. A., Kacmar, C. J., Douglas, C., \& Frink, D. D. (2005). Development and validation of the political skill inventory. Journal of Management, 31(1), 126-152.

Ferris,G.R., Solga,J.,Noethen,D\&Meurs,J.A.(2008).Political Skill Construct and Criterion -Related Validation:A Two Study Investigation.Journal of Managerial Psychology,23(7):744-771.

Ferris,G.R.,\&Treadway,D.C.(2012).Politics in organizations.Routledge.Taylor \& Francis Group.

Hellriegel, D.S. John, W.,(1996). Management, 7 th. ed. South western college publishing Cincinnati, ohio,

Hochwarter, W. A., Ferris, G. R., Gavin, M. B., Perrewé, P. L., Hall, A. T., \& Frink, D. D. (2007). Political skill as neutralizer of felt accountability_-job tension effects on job performance ratings: A longitudinal investigation. Organizational Behavior and Human Decision Processes, 102(2), 226-239.

Kaylee Ford,D.(2011). An evaluation of moderating influences of employee proactive personality: empowerment and political skill.(PHD dissertation). portland state university.

Lima C, Vicente et al. (2011). Corporate social responsibility, firm value and financial performance in Brazil. Social Responsibility Journal; 7 (2): $295-309$.

Marc O. (2000). Corporate Social Performance. Research Brief. Australia center for corporate change; 4-6.

Perrewé, P. L., Zellars, K. L., Ferris, G. R., Rossi, A. M., Kacmar, C. J., \& Ralston, D. A. (2007). Neutralizing Job Stressors: Political Skill as an Antidote to the Dysfunctional Consequences of Role Conflict. Academy of Management Journal, 47(1), 141-152.

Singhapakdi, A.; Vitell, S. J.; Rallapalli, K. C. \& Kraft K. (1996). "The Perceived Role of Ethics and Social Responsibility: A Scale Development", Journal of Business Ethics, Vol. 15, 1131-1140.

Vandermaat,M.(2008).Political behavior in middle management. The political skill of an effective middle manager during an organizational change. University of Nederland. Faculty of manangement.

Werner, W. J. (2009). "Corporate Social Responsibility Initiatives Addressing Social Exclusion in Bangladesh", J. HEALTH POPUL NUTR, Vol. 27, No. 4, 545-562. 